\title{
STRATEGI PENGAJARAN INTERAKSI SOSIAL KEPADA ANAK AUTIS
}

\author{
Aisti Rahayu Kharisma Siwi ${ }^{1}$ Nisa Rachmah Nur Anganti ${ }^{2}$ \\ ${ }^{1,2}$ Fakultas Psikologi Universitas Muhammadiyah Surakarta \\ 12aistikharismasiwi@gmail.com
}

\begin{abstract}
The purpose of this study is to understand the strategy of parents in teaching social interaction in children with autism. This research used qualitative method by conducting case study on 5 informants are 2 parents of autistic children, and one therapist from autistic children who are in Service Center Autis, Sragen. Based on the results of research, analysis, and discussion there are several strategies parents in teaching social interaction that imitate what is said by the informant, paste writing on the desk, invite children to play outdoors, introduce children to parents' friends when a visit at home, trying to entrust the child to her grandmother if the informant goes out, imitating what she sees like throwing garbage in her place, inviting children to play in the yard, taking her children's walks in the wild, for example in the fields or in the garden, informants with children, trained to stay focused on what the informants were instructing, to repeat what the informants taught, and to train the discipline in their daily activities. The strategy is done so that children want to interact with others.
\end{abstract}

Keywords: autism, social interaction, parenting strategies

Abstrak. Tujuan dari penelitian ini untuk memahami strategi orang tua dalam mengajarkan interaksi sosial pada anak penyandang autis. Penelitian ini menggunakan metode kualitatif dengan malakukan studi kasus pada 5 orang informan yaitu 2 orang tua dari anak autis, serta salah satu terapis dari anak autis yang berada di Pusat Layanan Autis, Sragen. Berdasarkan hasil penelitian, analisis, serta pembahasan terdapat beberapa strategi orang tua dalam mengajarkan interaksi sosial yaitu menirukan apa yang diucapkan oleh informan, menempelkan tulisan di atas meja belajar, mengajak anak untuk bermain di luar rumah, mengenalkan anak kepada teman orang tua jika bertamu di rumah, mencoba untuk menitipkan anak pada neneknya jika informan ke luar rumah, menirukan apa yang dia lihat misalnya membuang sampah di tempatnya, mengajak anak untuk bermain di halaman rumah, mengajak jalan-jalan anaknya di alam bebas misalnya di sawah ataupun di kebun, tanya jawab antara informan dengan anak, melatih untuk tetap fokus pada apa yang diperintahkan oleh informan, mengulang-ulang apa yang diajarkan oleh informan, serta melatih disiplin dalam melakukan kegiatan sehari-hari. Strategi tersebut dilakukan supaya anak mau berinteraksi dengan orang lain.

Kata Kunci: autis, interaksi sosial, strategi pendampingan orang tua

\section{PENDAHULUAN}

Kehadiran anak merupakan saat

yang ditunggu-tunggu dan sangat menggembirakan bagi pasangan suami istri. Kehadirannya bukan saja mempererat tali cinta pasangan suami istri, tetapi juga sebagai penerus generasi yang sangat diharapkan keluarga.

Menurut Hidayah (2013) anak yang terlahir sempurna merupakan harapan semua orang tua, mereka mendambakan memiliki anak yang sehat, baik secara jasmani maupun rohani, tetapi harapan itu 
tidak selalu dapat terwujud. Kenyataannya bahwa anak yang dimiliki berbeda dengan anak-anak lain pada umumnya merupakan salah satu hal yang harus diterima apa adanya. Walaupun anak tersebut tidak sama dengan anak-anak lain, orang tua wajib untuk menjaganya sampai dewasa, sehingga diperlukan peran penting bagi orang tua yang memiliki anak yang berbeda dengan anak-anak lain, misalnya dengan sering melakukan komunikasi antar anggota keluarga, maupun masyarakat. Anak autistik ditinjau dari masa kemunculannya atau kejadiannya dapat terjadi sejak lahir yang disebut dengan autistik klasik dan sesudah lahir dimana anak hingga umur 1-2 tahun menunjukkan perkembangannya yang normal. Tetapi pada masa selanjutnya menunjukkan perkembangan yang menurun atau mundur. Hal ini disebut dengan autistik regresi (Yuwono, 2009).

Menurut Puspitaningrum (2004) autistik klasik adalah adalah autisme yang disebabkan kerusakan syaraf sejak lahir. Kerusakan syaraf disebabkan oleh virus rubella (dalam kandungan) atau terkena logam berat (merkuri dan timbal). Sedangkan autistik regresif adalah autisme yang muncul saat anak berusia antara 12-24 bulan. Perkembangan anak sebelumnya relatif normal, namun setelah usia 2 tahun kemampuan anak menjadi merosot.

Yuwono (2012) mengemukakan bahwa beberapa tahun yang lalu, terjadi perdebatan mengenai angka statistik yang menunjukkan peningkatan jumlah anak yang didiagnosis sebagai anak dengan gangguan autistik. Sekitar 30 tahun yang lalu, angka kejadian anak dengan gangguan autistik antara 1-4 per 10.000 anak-anak. Setelah tahun 1990 jumlah anak-anak dengan gangguan autistik meledak semakin besar. Dalam hal ini memang kesulitan untuk menemukan data statistik secara akurat, tetapi angka perkiraan oleh lembaga penelitian menunjukkan $1-2 \%$ per 500 hingga $1 \%$ per 100 anak-anak. The Center for Desease Control (CDC) telah melaporkan 2-6 per 1000 anak-anak. Selama tahun 2000-2001 terdapat lebih dari 15.000 anak-anak berusia 3-5 tahun dan lebih dari 78.000 anak-anak berusia 6-21 tahun di Amerika Serikat adalah autistik sebagaimana didefinisikan dalam Individual with Disabilities Education Act (IDEA).

Dalam penelitian Karningtyas, Wiendijarti, dan Prabowo (2009) cara yang tepat untuk anak autistik dalam menyesuaikan diri dengan lingkungan sosial yaitu menggunakan teori interaksionisme simbolik, yaitu dengan bahasa non verbal atau simbol-simbol. Simbol-simbol yang menyatukan interaksi antara anak-anak autis dengan lingkungan sekitarnya dalam kaitannya dengan penelitian ini adalah penggunaan bahasa isyarat yang mencakup isyarat tangan dan gesture tubuh.

Saat melakukan hubungan sosial dengan lingkungan sekitar anak autis tidak mungkin sendirian. Pasti mereka akan didampingi oleh orang terdekat, misalnya ayah, ibu, kakak, adik, dsb. Muzaqi (2005) menjelaskan bahwa pendampingan merupakan salah satu pola asuh yang bermakna pembinaan, pengajaran, pengarahan dalam kelompok yang lebih berkonotasi pada menguasai, mengendalikan, dan mengontrol. Pola asuh sendiri merupakan pola pengasuhan yang berlaku dalam keluarga, interaksi antara orang tua dan anak selama mengadakan kegiatan pengasuhan (Tarmudji, 2002).

Adanya pendampingan atau seing disebut sebagai pola asuh akan mempermudah anak autis dalam melakukan interaksi sosial dengan lingkungan sekitarnya. Kesulitan yang dialami orangtua untuk mengajarkan interaksi kepada orang lain yaitu anak 
tersebut belum bisa fokus terhadap lingkungan, jika diajak berbicara masih melihat benda-benda di sekitar lingkungan dan tidak melihat orang yang diajak berbicara. Selain itu, karena anak tersebut dianjurkan diet makanan berbahan tepung, maka ibunya menghindari untuk memberikan makanan berbahan tepung, namun karena anak tersebut mempunyai adik, maka kadang kecolongan dalam melakukan pengawasan untuk tidak memberikan makanan berbahan tepung.

Berdasarkan uraian tersebut maka penelitian ini dilakukan untuk menjawab pertanyaan "Bagaimana strategi orang tua dalam mengajarkan interaksi sosial pada anak penyandang autis?"

\section{METODE PENELITIAN}

Penelitian kualitatif ini, peneliti menggunakan studi kasus. Informan dalam penelitian ini diambil secara purposive sampling, dengan kriteria yaitu orang tua yang memiliki anak autis dan melakukan terapi di PLA (Pusat Layanan Autis) Sragen. Disana terdapat 10 anak autis yang melakukan terapi, peneliti melakukan penelitian pada 2 orang tua (ayah ibu) dari anak autis, serta salah satu terapis dari anak autis sebagai informan pendukung. Penelitian dilakukan di Pusat Layanan Autis, Sragen. Data mengenai informan dapat dilihat di tabel.1 yaitu sebagai berikut:

Tabel 1

Data informan

\begin{tabular}{cllll}
\hline $\begin{array}{c}\text { Informan } \\
\text { ke }\end{array}$ & Inisial & $\begin{array}{c}\text { Jenis } \\
\text { kelamin }\end{array}$ & Usia & Status \\
\hline 1 & RWS & Laki-laki & 32 & Informan utama / orangtua subyek \\
2 & $\mathrm{R}$ & Perempuan & 29 & Informan utama / orangtua subyek \\
3 & $\mathrm{~S}$ & Laki-laki & 56 & Informan utama / orangtua subyek \\
4 & SM & Perempuan & 29 & Informan utama / orangtua subyek \\
5 & WNH & Laki-laki & & Informan pendukung / terapis anak autis \\
\hline
\end{tabular}

Pengambilan data dilakukan interaksisosial kepada anak autis dan dengan wawancara kepada kelima strategi orang tua dalam mendampingi informan. Wawancara dilakukan dengan anak autis saat melakukan interaksi sosial menggunakan guide wawancara yang panduan wawancara dapat dilihat di tabel. disusun untuk mengungkap bagaimana 2. Wawancara dilaksanakan di ruang peran orang tua dalam mengajarkan konsultasi Pusat Layanan Autis, Sragen.

. Tabel 2

Panduan Wawancara

\begin{tabular}{lcl}
\hline No & Pertanyaan & \multicolumn{1}{c}{ Sub Pertanyaan } \\
\hline 1 & Bahasa dan Komunikasi & Apakah bapak tahu bahwa anak bapak lain dengan \\
& anak-anak yang lain? \\
& Bagaimana cara bapak untuk mengajarkan bahasa dan \\
& komunikasi kepada anak tersebut? \\
& Apa kesulitan yang bapak alami saat mengajarkan \\
& berbahasa dan berkomunikasi kepada anak tersebut? \\
& Dimana bapak mulai mengajarkan berbahasa dan \\
& berkomunikasi kepada anak tersebut?
\end{tabular}




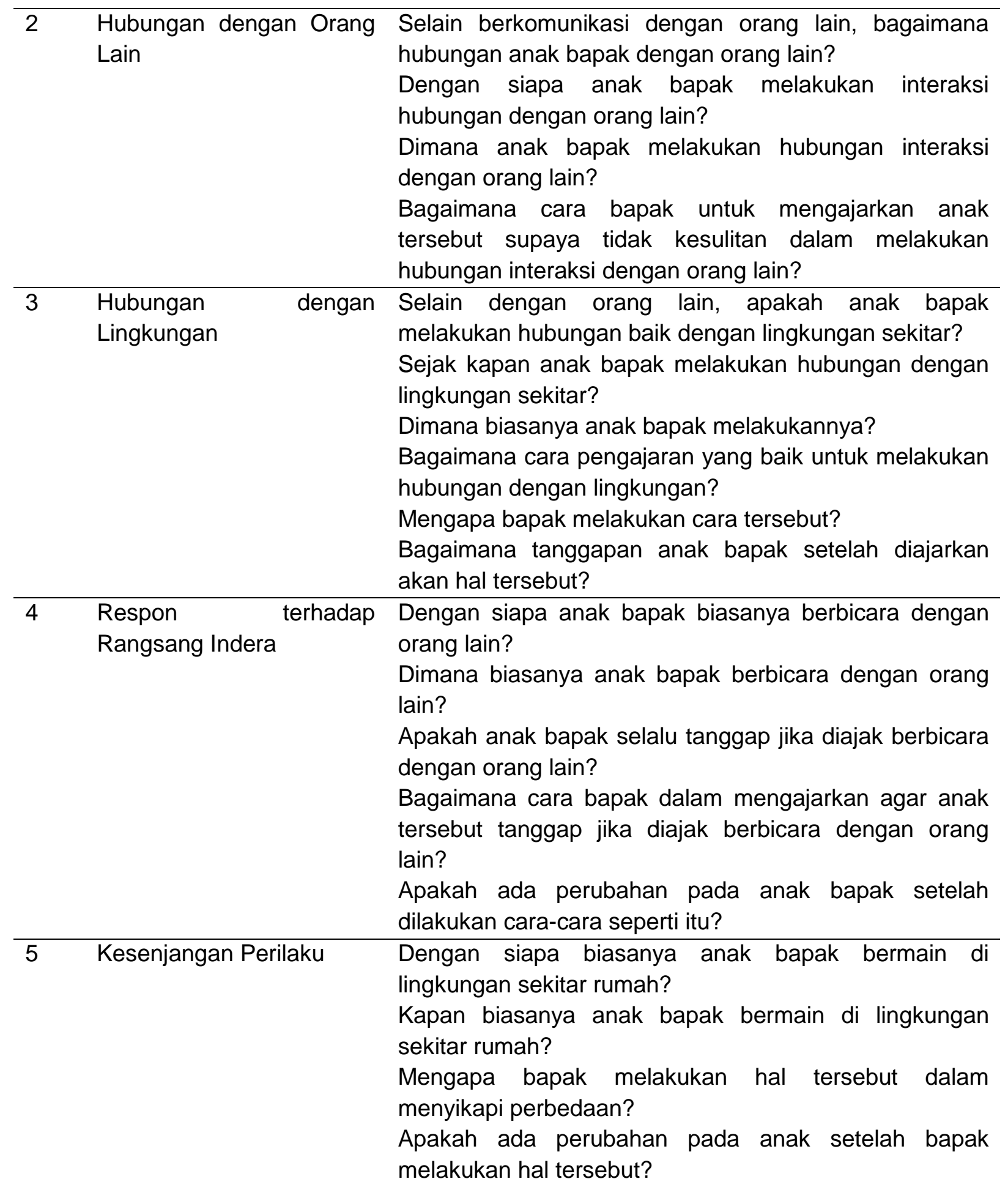

\section{HASIL DAN PEMBAHASAN}

Berdasarkan wawancara yang dilakukan diperoleh hasil bahwa informan pertama awal mulanya anak informan belum bisa berbicara sama sekali, padahal usianya sudah lima tahun. Dia sudah dibawa terapi ke kota lain, namun karena antrian banyak dan kurang efektif maka terapi tersebut jarang dilakukan. Anak informan hiperaktif, oleh karenanya susah dalam mengajarkan interaks sosial kepadanya. Namun, lama-kelamaan anak tersebut dapat berbicara dan berinteraksi dengan orang lain. Orang tua selalu mengajarkan anaknya setelah apa yang diajarkan di tempat terapi. Informan kedua 
Awal mulanya, anaknya hiperaktif sehingga jika diberi tahu akan sesuatu pasti tidak fokus. Anak tersebut hanya fokus jika ada mainan yang dia suka. Namun setelah mengikuti terapi di PLA, anak tersebut sudah mau berbicara dan berinteraksi dengan orang lain, walaupun harus difokuskan pada hal yang dituju.

Informan ketiga awalnya anak informan sudah dapat berbicara dan sudah dapat berjalan. Namun, Iamakelamaan perkembangannya mulai menurun karena lama menunggu saat mengikuti terapi di luar kota. Setelah itu, infoman memindahkan tempat terapis anaknya yaitu di PLA. Setelah di PLA, sudah mulai bisa berbicara kembali walaupun baru sepatah kata. Selain itu, untuk berinteraksi dengan orang lain, anak tersebut belum mau dikarenakan dahulu pernah dinakali oleh teman sebayanya.

Informan keempat awal mulanya anak informan hanya bisa menunjuk saat meminta barang, serta belum dapat berbicara sama sekali. Namun setelah mengikuti terapi di PLA, kurang lebih 7 bulan, lama-kelamaan anak tersebut dapat berkomunikasi dengan baik walaupun baru sepatah kata. Selain itu, untuk berinteraksi dengan lingkungan dan dengan orang lain, anak tersebut dapat berinteraksi dengan baik misalnya saat melihat kambing, sudah dapat mengatakan bahwa itu kambing. Dalam hal tersebut, informan selalu mengajarkan apa yang diajarkan saat terapi, jadi dapat berkesinambungan antara di rumah dan di tempat terapi.

Informan pendukung, terapis mengajarkan strategi interaksi sosial kepada anak autis dengan metode yang sama namun cara yang berbeda sesuai dengan tingkat keparahan anak tersebut. Biasanya, terapis mengajarkan cara menirukan, melihat, serta bermain bersama teman-teman yang lain. Cara yang dilakukan oleh terapis misalnya menirukan apa yang diucapkan olehnya, mengajarkan untuk membuang sampah setelah selesai terapi, serta bermain kelompok dengan anak lain pada satu minggu sekali. Hal tersebut efektif dilakukan oleh terapis, namun untuk hal bermain kelompok, lama-kelamaan yang mengikuti tidak banyak dikarenakan rumah pasien yang terlalu jauh.

Orang tua pastinya menghendaki bahwa anaknya tidak berbeda dengan anak yang lainnya, namun ternyata berbeda dengan anak lainnya. Orang tua dalam penelitian ini menghendaki bahwa anaknya dapat sembuh total, namun harus rutin dalam melakukan terapi.

Strategi yang dilakukan oleh orang tua hampir sama, yaitu mendampingi anak saat terapi, memfokuskan anak akan halhal tertentu, serta melakukan apa yang disarankan oleh terapis. Selain itu mereka juga akan selalu mengawasi mereka dari kejauhan, misalnya saat bermain dengan teman sebayanya. Orang tua merasa khawatir jika anaknya suatu saat akan berbuat apa yang tidak diinginkan olehnya, maka dari itu sesekali orang tua menasehati anaknya dengan pelan-pelan, satu atau dua kata. Salah satu yang diinginkan oleh orang tua kepada anaknya yaitu dapat berinteraksi sosial dengan baik. Interaksi sosial sendiri dapat memudahkan anak dalam memahami lingkungan sekitar.

Menurut Walgito (2003) interaksi sosial ialah hubungan antara individu satu dengan individu yang lain, individu satu dapat mempengaruhi individu yang lain atau sebaliknya, jadi terdapat adanya hubungan yang saling timbal balik. Penulis memaparkan bahwa terdapat beberapa tipe strategi interaksi sosial yang dilakukan oleh beberapa informan.

Berdasarkan hasil penelitian, ada beberapa strategi interaksi sosial yang dilakukan oleh beberapa informan. Yaitu Informan 1 (R.W.S.) pada aspek bahasa 
dan komunikasi, informan mengajarkan untuk menirukan apa yang diucapkan oleh informan. Pada aspek hubungan dengan orang lain, informan menggunakan strategi mengenalkan ataupun mengajak bermain dengan teman di sekitar rumah saat anak tersebut bermain dengan teman-temannya. Pada aspek hubungan dengan lingkungan, informan menggunakan strategi menirukan apa yang dilakukan oleh informan, misalnya dengan membuang sampah pada tempatnya. Pada aspek respon terhadap rangsang indera, informan menggunakan strategi menirukan apa yang diucapkan oleh informan. Pada aspek kesenjangan perilaku, informan menggunakan strategi melatih anaknya untuk tetap fokus serta disiplin dalam berbagai hal misalnya dalam belajar. Hal tersebut dilakukan oelh informan karena informan menginginkan bahwa anak tersebut dapat fokus jika diajak berbicara dengan orang lain, selain itu informan berharap bahwa anaknya tidak berbeda lagi dengan anak yang lainnya.

Informan kedua pada aspek bahasa dan komunikasi, informan menggunakan strategi mengajarkan serta menempelkan tulisan pada meja belajar anaknya. Pada aspek hubungan dengan orang lain, informan menggunakan strategi mengenalkan anak dengan lingkungan bermain di sekitar rumah dengan cara mengajarkan berbicara dengan orang lain. Pada aspek hubungan dengan lingkungan, informan menggunakan strategi menirukan apa yang dilakukan olehnya misalkan membuang sampah pada tempatnya. Pada aspek respon terhadap rangsang indera, informan menggunakan strategi menirukan apa yang diucapkan oleh informan. Pada aspek kesenjangan perilaku, informan menggunakan strategi melatih anak tersebut agar tetap fokus seta disiplin dalam belajar maupun kegiatan sehari-hari. Hal tersebut dilakukan oleh informan karena informan menginginkan bahwa anak tersebut dapat fokus jika diajak berbicara dengan orang lain, selain itu informan berharap bahwa anaknya tidak berbeda lagi dengan anak yang lainnya.

Informan ketiga pada aspek bahasa dan komunikasi, informan menggunakan strategi menirukan apa yang diucapkan oleh informan serta menempelkan huruf pada dinding yang sering dilihat oleh anaknya. Pada aspek hubungan dengan orang lain, informan menggunakan strategi mengenalkan anaknya dengan teman informan saat berkunjung ke rumah. Pada aspek hubungan dengan lingkungan, informan menggunakan strategi mengajak anaknya untuk bermain di halam rumah, walaupun anak tersebut belum mau untuk bermain dengan teman-temannya, setidaknya dia sudah mau melihat dari dalam rumah. Pada aspek respon terhadap rangsang indera, informan mengajarkan untuk bertanya kepada anaknya yang kemudian anak tersebut menjawab pertanyaan informan. Pada aspek kesenjangan perilaku, informan menggunakan strategi mengulang-ulang apa yang dia ajarkan. Hal tersebut dilakukan oleh informan karena informan menghendaki bahwa besok anak tersebut dapat mandiri serta sembuh, tidak bergantung pada orang lain jika ia sudah dewasa nanti.

Informan keempat strategi yang digunakan pada aspek bahasa dan komunikasi yaitu dengan menempelkan huruf pada meja belajarnya anak serta mengajarkan untuk berbicara kepada anak tersebut. Pada aspek hubungan dengan orang lain, informan menggunakan strategi mencoba untuk menitipkan anak tersebut kepada neneknya jika informan keluar, supaya anak tersebut mau dengan orang lain. Pada aspek hubungan dengan lingkungan, informan menggunakan 
strategi mengajak jalan-jalan anaknya di alam bebas seperti di sawah dan jalan. Pada aspek respon terhadap rangsang indera, informan menggunakan strategi bertanya kepada anaknya dan anak tersebut kemudian menjawab pertanyaan informan. Pada aspek kesenjangan perilaku, informan menggunakan strategi mengulang-ulang apa yang diajarkan oleh informan misalnya berbicara. Hal diatas dipaparkan oleh informan karena menurut infroman efektif, karena dilakukan setiap hari dan lama-kelamaan terdapat berubahan pada anaknya. Informan juga menginginkan bahwa anaknya sembuh dan dapat melebihi anak-anak yang lain dalam hal tertentu, misalkan di pendidikan. Pada informan pendukung, di aspek bahasa dan komunikasi, menggunakan strategi mengenalkan huruf dan angka pada buku yang disediakan oleh PLA dan mengajarkan membaca huruf tersebut. Pada aspek hubungan dengan orang lain, informan menggunakan strategi bermain kelompok dengan anak autis lainnya yang diadakan setiap satu minggu sekali di PLA. Pada aspek hubungan dengan lingkungan, menggunakan strategi menirukan apa yang dilakukan olehnya misalkan membuang sampah setelah selesai melakukan terapi. Pada aspek respon terhadap rangsang indera, menggunakan strategi tanya jawab antar informan dan anak autis, namun pertanyaan yang diajukan sesuai keparahan autis yang dialami anak tersebut. Pada aspek kesenjangan perilaku, menggunakan strategi mengulang-ulang apa yang diajarkan olehnya supaya anak tersebut tidak memiliki kesenjangan perilaku dengan teman-teman yang lainnya. Hal tersebut dilakukan oleh terapis karena beliau menginginkan bahwa anak yang beliau ajar bisa sembuh walaupun tidak sembuh total.

Informan pendukung berharap apa yang diajarkan di PLA dapat juga diajarkan di rumah, sehingga pada pertemuan berikutnya beliau hanya sedikit mengulas pelajaran yang kemarin serta dapat berkesinambungan antara pengajaran terapis di PLA dan pengajaran oleh orang tuanya di rumah. Saat semua strategi dilakukan oleh informan, ternyata anak mereka mengalami perubahan. Perubahan yang dialami anak tersebut berbeda-beda. Pada informan satu dan dua, anaknya sudah dapat berbicara dan menanggapi perkataan orang lain, selain itu saat berinteraksi dengan orang yang belum dia kenal, anak tersebut sudah mau berbicara. Pada informan ketiga, anaknya sudah bisa berbicara namun baru dengan keluarganya, jika ada teman yang bermain di rumahnya, anak tersebut belum mau untuk melakukan interaksi sosial. Pada informan keempat, anaknya sudah mau berkomunikasi namun baru sepatah atau dua patah kata, sedangkan jika bertemu dengan orang yang belum dia kenal, anak tersebut belum mau untuk berbicara dengannya.

Salah satu bentuk dalam melakukan interaksi yang baik yaitu membangun atensi bersama. Atensi bersama adalah kemampuan untuk berhubungan dengan orang lain secara verbal maupun tidak, di sekitar pengalaman, objek atau kejadian yang dimiliki bersama. Orang tua dapat membangun atensi bersama dan memampukan anak berinteraksi dengan baik misalnya dengan cara membuat kelompok teman sebaya yang mendukung dalam berinteraksi (Sastry \& Aguirre, 2014). 


\section{SIMPULAN}

Berdasarkan hasil penelitian,
analisis terdapat beberapa strategi pendampingan orang tua dalam mengajarkan interaksi sosial kepada anak autis yaitu strategi yang dilakukan oleh orang tua pada aspek bahasa dan komunikasi yaitu menggunakan strategi menirukan apa yang diucapkan oleh informan serta menempelkan tulisan di atas meja belajar.

Strategi yang dilakukan oleh orang tua pada aspek hubungan dengan orang lain menggunakan strategi mengajak anak untuk bermain di luar rumah, mengenalkan anak kepada teman orang tua jika bertamu di rumah, serta menggunakan strategi mencoba untuk menitipkan anak pada neneknya jika informan ke luar rumah.

Strategi yang dilakukan oleh orang tua pada aspek hubungan dengan lingkungan yaitu menggunakan strategi menirukan apa yang dia lihat misalnya membuang sampah di tempatnya, mengajak anak untuk bermain di halaman rumah, serta mengajak jalan-jalan anaknya di alam bebas misalnya di sawah ataupun di kebun.

Strategi yang dilakukan oleh orang tua pada aspek respon terhadap rangsang indera yaitu, pada menggunkan strategi tanya jawab antara informan dengan anak. Strategi yang dilakukan oleh orang tua pada aspek kesenjangan sosial yaitu, pada menggunakan strategi melatih untuk tetap fokus pada apa yang diperintahkan oleh informan mengulang-ulang apa yang diajarkan oleh informan, serta mengulangulang apa yang diajarkan oleh informan serta melatih disiplin dalam melakukan kegiatan sehari-hari. Strategi tersebut dilakukan oleh orang tua supaya anak mereka mau berinteraksi dengan orang lain.

Berdasarkan penelitian maka saran yang dapat diberikan oleh peneliti yaitu orangtua dapat menggunakan strategi yang dapat dilakukan dan mudah dipahami oleh anaknya misalkan dengan menempel huruf atau gambar di dinding kamar tidurnya, supaya saat anak bangun tidur dapat langsung melihat dan tahu akan nama huruf dan gambar. Mengajarkan untuk melakukan interaksi di luar rumah, misalnya dengan teman sebaya atau tetangga sekitar agar anak tersebut tidak takut akan dunia luar. Mengajarkan disiplin pada anak misalkan dibuat jadwal dari jam dia bangun sampai tidur kembali supaya anak tersebut dapat terbiasa. Selain orang tua, di Pusat Layanan Autis sebaiknya, pada dinding atau meja untuk terapi anak dibuatkan tempelan yang berupa tulisan atau gambar supaya anak lebih cepat tanggap dalam berbicara. Mengaktifkan kembali terapi kelompok yang selama ini belum dilakukan secara rutin setiap satu minggu sekali.

\section{DAFTAR PUSTAKA}

Hidayah, N. (2013). Kebermaknaan hidup orang tua yang memiliki anak autis (Skripsi, UIN Sunan Kalijaga, Yogyakarta). Diunduh dari http://digilib.uin-suka.ac.id/12434.

Karningtyas, M. A., Wiendijarti, I., Prabowo, A. (2009). Pola komunikasi interpersonal anak autis di sekolah autisme fajar nugraha yogyakarta. Jurnal IImu Komunikasi, 7(120), 120-129. 
Muzaqi, M. (2005). Pengaruh pendampingan tutor terhadap motivasi belajar warga belajar PKBM taman belajar kecamatan Kenjeran Surabaya (Tesis, Universitas Airlangga, Surabaya). Diunduh dari http://www.damandiri.or.id/file/muzaquiunair

Puspitaningrum, D. (2004). Peran keluarga pada penanganan individu autistic spectrum disorder. Diunduh dari http://puterakembara.org/ rm/peran_ortu.htm

Sastry, A. \& Aguirre, B. (2014). Parenting anak dengan autisme: Solusi, strategi, dan saran praktis untuk membantu keluarga anda. Yogyakarta: Pustaka Pelajar.

Tarmudji, T. (2002). Hubungan pola asuh orang tua dengan agresivitas remaja. Jurnal Pendidikan dan Kebudayaan, 8(37), 504-519.

Walgito, B. (2003). Psikologi sosial suatu pengantar. Yogyakarta: Andi.

Yuwono, J. (2012). Memahami anak autis: Kajian teoritis dan empirik. Bandung: Alfabeta. 